\title{
Impressões sobre Paris e Auschwitz em tempos de terror: fragmentos de um diário de campo
}

\author{
Impressions on Paris and Auschwitz in times of \\ terror: fragments of a field diary
}

\begin{abstract}
RESUMO
O texto apresenta o registro de duas experiências vividas pela autora no período em que morou na França para realização de parte do doutorado (PDSE). A estudante de doutorado, que pesquisava o tema da morte para sua tese, é surpreendida pelos ataques terroristas em Paris em novembro de 2015 e alguns meses depois ela visita o campo de concentração de Auschwitz. A partir do conceito de "corpo vibrátil" da cartografia de afetos, a autora descreve em primeira pessoa o impacto que as experiências produziram em seu corpo. O texto é um relato de campo despretensioso, que pretende compartilhar os acontecimentos, apresentando algumas reflexões sobre seus impactos observáveis na cidade e na vida dos moradores, e sobre as diferenças nos modos de lidar com o medo da cidade em que vive, o Rio de Janeiro.
\end{abstract}

Palavras-chave: Morte - Paris - Auschwitz - Terrorismo - Medo

\begin{abstract}
The text presents the record of two experiences lived by the author in France during the realization of the part of the PhD degree. The doctorate student, who researched the subject of death for her thesis, was surprised by the terrorist attacks in Paris in November 2015, and visits the Auschwitz concentration camp a few months later. Using the "vibrational body" concept of cartography of affections, the author describes in first person the impact of these experiences on her body. The text is an unpretentious field report that intends to share the events bringing some reflections on its observable impacts on the city and the life of the residents and on the differences in the ways of dealing with the fear of the city where she lives, Rio de Janeiro.
\end{abstract}

Keywords: Death - Paris - Auschwitz - Terrorism - Fear

* Doutora em Psicologia pela Universidade Federal Fluminense - UFF, Brasil. Professora Assistente no curso de Psicologia na Universidade Estácio de Sá - UNESA, Brasil. CV: http://buscatextual. cnpq.br/buscatextual/visualizacv.do? id =K4458530P8 


\section{O enamoramento com a morte}

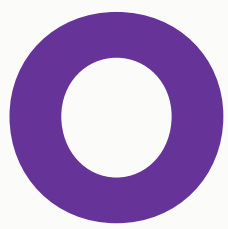

tema da morte me interessa há muito tempo, meu primeiro escrito sobre a questão foi ainda durante a graduação, quando fiz estágio em psicologia clínica com pacientes oncológicos. Nesse hospital assisti pela primeira vez a vida deixar um corpo, condensando num instante quase mágico a transformação daquilo que era uma pessoa numa massa inerte e sem vida, um pedaço de carne, um cadáver. 0 caráter enigmático dessa transformação me marcou tão profundamente que reverbera até hoje, tornando possível entender a necessidade humana de inventar lógicas para capturar o que há de imperscrutável nesse acontecimento.

A escolha desse estágio não foi aleatória, já havia ali um enamoramento pela questão, alimentado pela minha história pessoal. Eu era uma daquelas crianças de quem muitos tinham dúvidas se 'vingaria'. Minha saúde durante a infância foi marcada pela confluência estranha de doenças raras e sem explicação, todas com alto risco de morte, culminando com um choque anafilático aos sete anos que, além de três ou quatro minutos com o coração parado, teve como consequência quinze dias de coma, e uma difícil e longa recuperação cardiorrespiratória.

Durante anos pude pensar pouco no assunto, como todos parecem fazer, mas há alguns anos descobri uma cardiopatia atípica, que me fez reviver e repensar o problema. Naqueles meses em busca de um diagnóstico - passando pela investigação de cinco tipos diferentes de câncer entre outras tantas doenças, disfunções, síndromes, etc. - veio uma das primeiras pistas daquilo que se transformaria em meu objeto de pesquisa: não é fácil aprender como lidar com a própria mortalidade, pois não é de 'bom tom' falar de morte, morrer é um ato de mau-gosto, um incômodo que se imputa aos que nos cercam.

Em 2012 ingressei no curso de Doutorado em Psicologia da UFF, com o projeto de cartografar a experiência de morrer no contemporâneo. Ao tomar a temática da morte como um dispositivo de análise, pretendeu-se indagar como a experiência da morte atravessa e constitui a experiência de vida e vice-versa, dando especial enfoque para as formações da violência no cotidiano da cidade do Rio de Janeiro, onde passei a residir desde 2006.

Durante o processo de elaboração da pesquisa, desde a apresentação do pré-projeto para a seleção do doutorado até a sua conclusão, a pergunta que mais escutei também foi a que mais me coloquei: "por que falar sobre morte?" e a resposta sempre parece vir nessa forma: "Por que não?", ou dito de outro modo: "qual a problemática que é levantada que torna tão estranho, tão marginal ou pouco comum a enunciação da morte?"

Considera-se, no senso comum, que há certa morbidez nessa preocupação, que mais combina com pessoas vestidas de negro, com maquiagem pesada e que se encontrariam bem ambientadas entre os entes da família Adams. Muitos autores concordam que a morte se tornou um tabu no discurso moderno, comparável ao sexo em outros tempos: "As atitudes defensivas e o embaraço com que hoje as pessoas reagem a encontros com moribundos e com a morte são comparáveis às reações das pessoas com encontros abertos com aspectos da vida sexual na era vitoriana" (Elias, 2001, p. 52). Pensamos que todo território interditado, aquele do qual 
não se pode falar, pode ser revelador das relações de poder existentes na sociedade, razão pela qual merece ser observado detalhadamente.

Durante os anos de pesquisa conheci e passei a estudar o filósofo holandês Baruch de Spinoza do século XVII, sobretudo pela proximidade e afinidade com minha orientadora, Cristina Rauter, estudiosa deste autor. Apesar de secular, sua obra, mais atual do que nunca, está se tornando cada vez mais lida e discutida nas regiões mais críticas da filosofia, ciência política, economia, neurociência, psicanálise e sociologia. Sua concepção inovadora de corpo e sua ética de afetos constituem solo fértil para problematizar a relação do homem com sua mortalidade. Assim, minha tese foi se direcionando para o entendimento da morte na filosofia spinozista.

No início de 2014 fui selecionada para uma bolsa do tipo PDSE de seis meses na Université de Picardie Jules Verne, de Amièn, na França para estudar com o filósofo Lourenço Vinciguerra, estudioso de Spinoza. Por problemas políticos no Brasil, o programa foi suspenso nacionalmente e, em outubro de 2015, parti para Paris com apenas alguns recursos pessoais para uma breve, mas muito proveitosa estada de três meses.

\section{Maquinas de morte: um mergulho no terror}

No período vivi duas experiências muito marcantes: os ataques terroristas em Paris em novembro de 2015, e uma visita ao campo de concentração de Auschwitz, em janeiro de 2016. Apesar de separadas décadas pelo tempo e situarem-se distantes em territórios mil e quinhentos quilômetros, essas experiências se fizeram acontecimentos em mim, por evidenciarem duas tecnologias de matar e de produzir medo, que denominarei aqui de maquinarias de produção de morte. Gostaria então, de deixar registrado o contato com essas máquinas, porque mesmo não entrando diretamente na minha pesquisa naquela ocasião, atravessaram as ideias desenvolvidas durante toda a tese, à medida que produziram no meu corpo afetos determinantes para a construção da escrita. Este texto então é uma espécie de fragmento de um diário de campo, um modo de dar visibilidade a esses acontecimentos.

Suely Rolnik (1989) desenvolveu o conceito de corpo vibrátil, apontando um movimento dentro do método cartográfico, onde o pesquisador volta a atenção para as vibrações que invadem seu próprio corpo, no contato com o campo. Segundo a autora, é preciso voltar à atenção aos afetos produzidos nesse encontro, pois fazem parte da pesquisa, tanto quanto a informação formal coletada, evidenciando assim que pesquisador e objeto pesquisado estão em constante relação, produzindo-se mutuamente. $O$ acontecimento a ser estudado é então aquilo que reverbera no corpo do pesquisador, e não é um fato observado em campo exterior; a pesquisa se compõe nas pistas dos afetos, dos gestos, da poesia, das observações. Assim, o verso: "é preciso estar atento e forte, não temos tempo de temer a morte", que durante todo o caminho ecoou repetidamente nos meus pensamentos, como uma música em que não se consegue parar de pensar, foi acolhido e escutado, fazendo mais e mais sentido a cada etapa do caminho, ditando a cadência da escrita e dos afetos que acompanhariam os acontecimentos 
que ainda estavam por vir.

Por intermédio do testemunho dos efeitos das experiências atravessando meu corpo, espero que seja possivel acompanhar o caminhar de um coração brasileiro por esses dois contextos de coação de vida. É preciso reforçar que a intenção aqui não é relatar ou retratar os eventos de maneira incontestável, mas meu percurso afetivo no contato com esses lugares. Paris, Auschwitz e Rio de Janeiro são realidades distintas, porém têm em comum uma política que faz do ato de matar uma prática, e do medo uma poderosa arma.

\section{Paris}

Fazia pouco mais de 20 dias que eu tinha chegado a Paris, acompanhada pelo meu marido, para cursar o estágio sanduíche. Depois de um período muito tenso de preparação de viagem, era hora de relaxar. Eu havia perdido, de última hora, a bolsa concedida mas ainda não homologada, quando já estava afastada do trabalho em uma universidade privada, em licença não remunerada para aprimoramento. Já se aproximava a data de embarcar quando foi confirmado que meu processo estava fora daquele último lote de bolsas e, nesse momento, não havia tempo para sentir essa perda. Eu havia ganhado a bolsa em concurso interno na minha instituição de ensino, planejei minha viagem, despendi dinheiro e tempo estudando francês, escrevendo projetos, trocando correspondências, fazendo traduções, providenciando documentos, etc., e não consegui me demover da ideia que passei anos planejando. Decidi então que iria financiar meus próprios estudos e reduzi a viagem de oito para três meses. Nesse momento, meados de 2015, não sabíamos que essa quebra de contrato era apenas a primeira das que se multiplicariam nos próximos anos, devastando direitos adquiridos e assegurados em lei de todo o povo brasileiro.

Como meu orientador estava fora da cidade, tivemos o privilégio de passear muito durante a primeira semana, conhecendo uma Paris que não veríamos mais, uma Paris antes dos atentados. O clima era um pouco pesado, é verdade, pois menos de um ano havia se passado desde o ataque ao jornal Charlie Hebdo, em 07 de janeiro do mesmo ano. A explosão de uma bomba seguida de tiroteio, que matou 12 pessoas e feriu outras 11, foi interpretada como represália à edição do jornal que satirizava valores do mundo islâmico, trazendo uma representação do poeta Maomé. Houve outros ataques de menor tamanho nos dias que se seguiram, totalizando 19 mortos. Apesar de ter mobilizado a opinião pública mundial em solidariedade aos franceses, com o movimento "Je suis Charlie", era possível sentir que os efeitos desse acontecimento já pareciam estar sob controle.

Percebíamos a tensão no ar quando entrávamos em shoppings, supermercados ou lojas e solicitavam que abríssemos a mochila para mostrar o conteúdo, como uma maneira de prevenir que bombas fossem colocadas nestes ambientes. Foi impossível não pensar que para nós, brasileiros, era mais familiar ter suas bolsas revistadas na saída, como medida antifurto, dando visibilidade ao contraste dos medos entre esses dois mundos. Essa medida de revista certamente não fazia parte da rotina de cidadãos franceses nem de boa parte dos europeus. 
A revista era rotineira, mas não era rígida, percebíamos que os próprios seguranças não esperavam realmente encontrar algo ali. Refletindo a posteriori é possivel indicar a diferença de impacto desse atentado para os que se seguiriam: tinha um alvo específico (Charlie Hebdo) e um motivo delimitado (desrespeito ao Islã pela representação do profeta Maomé).

Como nossa reserva na Cité Universitaire só começava em alguns dias, resolvemos viajar para Portugal e Espanha, experimentando uma segurança rígida nos aeroportos, com um clima ainda descontraído. Nessa viagem passei pela segurança com uma goiabada (ótimo presente, tanto para europeus, que o decoro recomenda levar uma lembrancinha, quanto para conterrâneos apartados de casa), que foi apenas apalpada, e recebi um pedido de desculpas sinceras pelo confisco de um frasco de shampoo que excedia o tamanho permitido - o fiscal não queria retê-lo, sabia que não era nada, mas precisava seguir as normas.

Voltamos a Paris na quinta-feira, véspera dos atentados, decidimos seguir para a Normandia para passar o final de semana, já que nossa reserva na residência só iniciaria na segunda-feira. No momento do início dos atentados, na sexta-feira, dia 12 de novembro, às 21horas, estávamos embarcando em um ônibus em Port Maillot, em La Defense, que fica exatamente no meio do caminho entre os dois principais locais dos atentados, a Place de la République e o Estádio de Sant Denis. Ao sair de Paris, passamos quase em frente ao estádio momentos antes das primeiras explosões, mas de nada sabíamos por ainda desconhecer a geografia da cidade. Por sorte, antes de embarcar, havíamos falado com familiares, avisando que estávamos deixando a cidade e, ao entrar no ônibus, ficamos sem conexão.

No ônibus, depois dos atentados, tentei sintonizar uma estação de rádio, mas havíamos chegado há pouco tempo e não tínhamos fluência na língua. Ninguém no ônibus conversou, falou em voz alta ou fez qualquer comentário, ligou para parentes ou amigos, enfim, não era possível supor que algo tão sério estava acontecendo, tamanha a reserva dos passageiros, de modo que não dei valor à expressão 'noite de sangue', 'noite de terror' que escutei, entre tantas palavras desconexas, na locução da rádio. É difícil não imaginar que se fosse no Brasil, o ônibus inteiro discutiria coletivamente a situação durante toda a viagem.

Chegamos no hotel de madrugada e esquecemos de pedir a senha do wi-fi. No sábado, ao conectar os telefones, o grande susto: dezenas de mensagens de familiares e amigos perguntando como estávamos, além de alertas para não tentarmos voltar pra Paris. Levamos um tempo até entender o que estava se passando. Por longos instantes, olhamos abismados um para o outro, e para os telefones, tentando compreender a dimensão dos fatos e a nossa segurança naquele momento. Ligamos a televisão e recebemos as primeiras imagens, mas nenhum de nós tinha ainda habilidade de compreensão da língua falada, sobretudo com tamanha emoção e rapidez. Então, tudo o que tínhamos eram imagens de cenas dos ataques e a cidade deserta, completamente esvaziada, com o exército na rua. Conseguimos falar com amigos que estavam em Paris que nos asseguraram que as coisas estavam se acalmando, mas era melhor permanecermos lá por alguns dias, pois todas as fronteiras estavam fechadas e, mesmo dentro do país havia barricadas em torno de toda a cidade.

Voltamos na segunda-feira para uma cidade estranha. Era visível o movimento restrito na rua e as pessoas pareciam extremamente assustadas. Atravessamos a cidade de Metrô, do 
ponto mais extremo do Norte ao ponto mais extremo do sul, e cruzamos com poucas pessoas na rua, mas com muitos militares que antes pouco se notavam. Mesmo estações como a Gare du Nord ou Gare Chatelet, pontos de aglutinação de linhas de transporte, sempre lotadas de gente, havia poucos transeuntes.

Carreguei a sensação de que não sabia exatamente como me sentia diante da surpresa, ou como deveria me sentir naquele momento. Aos poucos fui percebendo que eu não era a única a me sentir assim. A situação era nova e inusitada, não havia um protocolo a seguir. Com aulas canceladas, museus fechados e pouca gente na rua, encontramos com poucas pessoas naqueles dias, e logo percebemos que não se falava em outra coisa. Na Maison du Brésil, onde estávamos hospedados na Cité Universitaire, as atitudes eram as mais diversas, desde pessoas que começavam a estocar comida em seus quartos, passando pelos que choravam continuamente e queriam voltar para casa, até os destemidos que achavam o perigo distante. A direção da residência ofereceu um espaço e um profissional para um grupo de compartilhamento de sentimentos que ficava ao lado do nosso quarto, de maneira que pudemos observar que foi muito utilizado pela população da casa.

Vários portões de acesso à Cité Universitaire foram fechados, inclusive o que mais usávamos. Vale lembrar que se trata de um grande complexo, que contém um bosque e cerca de quarenta edifícios, com residências de 19 países e cerca de 5.800 quartos. As revistas na entrada passaram a ser muito rígidas. Antes elas aconteciam somente na entrada do prédio central de modo rápido e displicente. Passaram a ser realizadas nos únicos dois portões de acesso que permaneceram abertos, gerando filas para a entrada. Dá para imaginar o que é voltar com as compras da semana do supermercado e ter que abrir para mostrar todas as sacolas com alimentos? E as pessoas que faziam mudanças com malas e objetos, fato extremamente comum na rotina de uma moradia temporária? Tudo deixaria evidente para todos que aquele lugar, por ser um espaço de liberdade, agregador de várias culturas, era um alvo em potencial de um provável novo ataque.

Entre os franceses, percebia-se desde pensamentos integradores, que compreendiam as forças em jogo e o tamanho da batalha em questão até atitudes fascistas e xenofóbicas em relação aos imigrantes muçulmanos. Nas eleições municipais que aconteceram nas semanas seguintes, o número de candidatos de extrema direita eleitos cresceu muito além do esperado, o que deve resultar em medidas mais protecionistas contra imigrantes, mostrando que as implicações subjetivas do medo afetam a vida de toda a comunidade.

Os grupos de conversação em língua francesa oferecidos pela Cité, que reúne estudantes de todas as nacionalidades para exercitar a língua falada, passaram a refletir a onipresença desse assunto. A população de estudantes, que é formada por jovens estrangeiros já fragilizados pela distância de casa e provenientes de lugares acostumados a viver em tranquilidade, parecia ainda muito perdida, como se eles estivessem se deparando pela primeira vez com o de temor pela própria vida.

Eu, confesso, estava no grupo dos que não sentiam tanto medo. O primeiro grande aprendizado quando cheguei na Europa foi o de não temer todo o tempo pela minha segurança pessoal. Era difícil conceber que este não era o critério número um para tomar decisões acerca 
de quase tudo: a hora de sair, o trajeto a percorrer, o que sentir por um desconhecido que cruza seu caminho ou quando avista alguém correndo. Todos avisaram que havia furtos, de modo que era preciso tomar cuidado, mas os assaltos eram absolutamente incomuns. Certa vez, em Lisboa, perguntei a um policial sobre um caminho e depois de receber as orientações, perguntei se era seguro naquela hora. Ele não conseguia sequer entender o que eu estava perguntando, pois sequer imaginava qualquer tipo de violência durante o trajeto.

Eu e meu marido conversamos várias vezes sobre certa ideia de justiça poética contida no furto, que exige o investimento no desenvolvimento de uma habilidade - o mais hábil em se proteger ou em roubar leva o prêmio -, enquanto o assalto é um enfrentamento da ordem da covardia, leva o mais forte ou mais armado e a sua simples existência tem boas chances de acabar em tragédia. Aprendemos a dificultar o acesso ao dinheiro, escondendo-o sob as muitas camadas de roupa e a não nos distrair em trens ou ônibus lotados, mas aos poucos nos acostumamos com a ideia de não temer pela própria vida e pelas parcas propriedades pessoais, à medida em que entendíamos a dimensão que isto ocupava na nossa existência no Brasil.

Os dias que se seguiram foram tensos. Na quarta-feira, um grande confronto com a polícia fechou as ruas de Sant Denis e anunciou a morte dos supostos terroristas. Os anúncios pelo rádio, televisão, redes sociais e e-mail, pedindo para as pessoas não saírem de casa, sem dúvida eram ameaçadores. Seguiu-se certo alívio após essa investida policial, que foi considerada como bem-sucedida, pois acreditava-se na iminência de outro ataque por esta célula terrorista que agora fora destruída. Ao mesmo tempo, a fragilidade daquele sistema estava exposta.

Tudo havia mudado. Outra goiabada, idêntica à primeira, ficou retida no aeroporto em uma viagem à Itália no final de semana, onde também passamos por uma revista minuciosa por agentes fardados com cara de poucos amigos. O procedimento de aeroporto mudou e fomos recebidos como visitantes que entravam na Europa pela primeira vez, passando por todo o procedimento de imigração. Na entrada pela Bélgica (antes dos atentados nesse país, em 22/03/2016), depois de outro passeio, demoramos mais de três horas para atravessar a fronteira de ônibus, em decorrência do procedimento super criterioso de entrada. Nas portas dos museus, lojas e escolas, os seguranças já não tinham a mesma cordialidade, nem o agir de quem cumpre uma formalidade. Nas ruas era evidente o esvaziamento. Semanas depois levamos uma amiga à Torre Eiffel, onde não encontramos as tradicionais longas filas, e visitamos o Museu do Louvre num domingo de portas abertas (sem cobrança de ingresso, que acontece uma vez ao mês), conseguindo circular com tranquilidade, e até chegar perto de obras usualmente ofuscadas pelo excesso de público, como a Monalisa ou a Vênus de Milo, eventos impensados meses antes. Na Place de la République, um dos pontos atacados, milhares de pessoas passavam prestando suas homenagens aos mortos, depositando velas e flores. Corria por lá uma história que contava que todos correram assustados quando escutaram um estrondo, que depois se verificou ser de uma lanterna de vela.

Sempre que inquirida sobre como me sentia, sentia-me constrangida em dizer que não sentia medo. Era irreal pensar que ali, naquela cidade sem assaltos e confrontos armados urbanos, eu corria mais perigo do que indo trabalhar. Eu, que moro em Copacabana e dou 
aulas noturnas em Santa Cruz e na Taquara, na zona Oeste do Rio de Janeiro, atravesso toda a extensão da Avenida Brasil ou da Cidade de Deus à meia noite, vendo e ouvindo tiroteios à distância e, até balas que deixam rastros de fogo, ao cruzarem o ar poucos metros à frente do meu caminho.

Mesmo não conseguindo sentir o mesmo medo que os moradores de Paris, não era difícil entender o que eles sentiam. Eles, que não conheciam minha realidade, que ainda não tinham, como eu, desenvolvido mecanismos para negar o medo porque é preciso trabalhar, como nas palavras de Chico Buarque "tragar a dor e engolir a labuta". Para quem conhece a tranquilidade, perdê-la é como ser apunhalado, é um tipo de morte, pois condena a viver no medo. O primeiro atentado, em janeiro de 2015, tinha um alvo e atingiu pessoas que, de alguma maneira, haviam desafiado o Islã. Esse era aleatório, obedecia outra lógica, poderia acontecer com qualquer um que simplesmente estivesse na hora errada no lugar errado. A sensação de que, a qualquer momento e sem motivo pessoal, alguém que você nem conhece pode investir contra sua vida é aterrorizante e muda completamente a economia de afetos de uma comunidade. O medo passa a ser um afeto difícil de ser ignorado e fazê-lo exige doses cada vez maiores de esforço. Quando essa realidade é enxergada assim, com um olhar mais distante, só faz ressoar a incômoda pergunta: como convivemos (cariocas e brasileiros) com essa ameaça à vida o tempo todo?

Durante anos lendo Michael Foucault - aponto principalmente os livros Vigiar e Punir (1996) e Em Defesa da Sociedade (2000), onde o autor trabalha os conceitos de poder disciplinar e biopoder - nos indagamos sobre as artimanhas que o poder inventa para se tornar cada vez mais invisível, ao mesmo tempo em que se faz cada vez mais eficiente. Como, em pleno raiar do terceiro milênio, lidar com essa tecnologia que remete aos tempos da soberania, onde as estruturas de extermínio se tornam tão salientes, tão visíveis e, nesse aspecto, tão semelhantes, às favelas cariocas?

Nós não sabíamos o que estava por vir quando deixamos Paris, mais de dois meses depois dos ataques - ainda aconteceriam os atentados em Bruxelas, Nice, Munique e outros tantos em diversas cidades do mundo - mas tínhamos certeza de uma coisa: os europeus teriam que, a partir de agora, aprender a conviver, como nós, com o medo constante.

\section{Auschwitz}

É bem difícil falar de Auschwitz. Quando comento com alguém que fiz essa visita, as pessoas me interrogam sobre esse lugar, como se fosse um inferno cheio de péssimas vibrações. Talvez seja verdade, mas não é por isso que acho difícil falar desse lugar. É que tudo, absolutamente tudo lá é novo, diferente e impensável. Para mim, o mais difícil de digerir era buscar entender como uma prática de confinamento e extermínio pôde se transformar em uma política formal e duradoura de Estado, separada do nosso tempo por apenas um punhado de décadas.

Pisar em um lugar que você conhece pela tela de cinema produz uma sensação 
complexa porque o primeiro sentimento é que se está em um cenário e, consequentemente, que os eventos passados lá são ficção. Digo isso por ter sentido uma estranha amortização na intensidade dos afetos. Fiquei refletindo sobre essa sensação e me propus a fazer um exercício de familiarização com a paisagem antes de começar a visita. O cheiro de cemitério (cheiro de flores velhas, quando a água já está meio podre) que vinha de uma lojinha de flores ajudou a estabelecer contato com o ambiente, desviando dos afetos pret-à-porter, na intenção de singularizar minha experiência. Foi preciso repetir mentalmente: existiu mesmo, não é o cenário de um filme porque a realidade é tão surreal que parece não ter acontecido.

Optamos por fazer a visita sem guia turístico, apenas com o material impresso comprado na loja. A princípio, era uma preferência prática, pois o próximo grupo em francês ou espanhol demoraria algumas horas para sair, se mostrou uma escolha diferenciada porque os guias, ligados intimamente às causas semitas, carregavam no tom ao relatar as histórias, contando requintes de crueldade em cada momento de parada, incitando a sensibilidade dos ouvintes às dores daquele povo. Encontramos com eles e os escutamos durante todo o percurso, mas mantivemos nossa percepção mais preservada dos sentimentos que eles faziam questão de imprimir em sua audiência.

A ideia central da organização do museu é causar um efeito impactante. Tudo gira em torno da questão do tamanho: é preciso dimensionar essa tragédia. Uma história contada inúmeras vezes - em aulas, livros, peças e filmes - corre o risco de banalização e de ser separada da carga de afetos que ela carrega, quando se faz contato nas primeiras vezes, de forma que é preciso inventar uma maneira de ela continuar a ser impactante, para que nunca faça parte do passado totalmente.

Figura 1 - Portão de entrada do campo de Auschwitz I

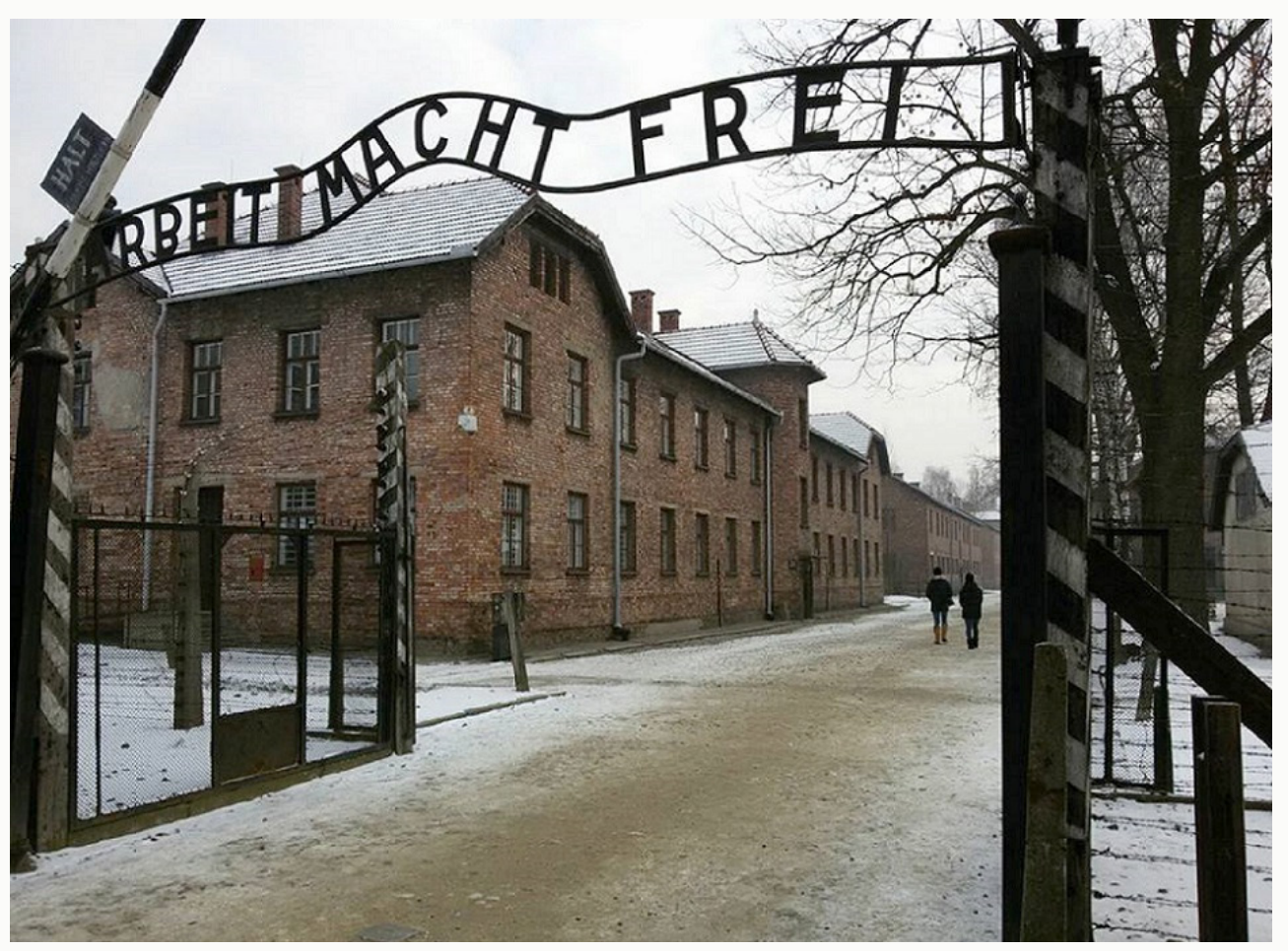

Fonte: Fotografia da autora (18/01/2016) 
A sensação de estar em um cenário se torna nítida quando se atravessa o portão de ferro com as palavras em alemão "Arbeit macht frei": o trabalho liberta. A primeira ideia do campo, como mostra o filme A Lista de Schindler, era ser um lugar de confinamento de trabalho escravo por prisioneiros de guerra. Fizemos a visita no início do inverno, em janeiro, quando entendemos por que todos os filmes destacam as cenas nesta estação. Fazia treze graus negativos e tudo estava coberto por uma grossa e compacta camada de neve. A palheta de cores desafia o olhar e pinta tudo de branco, desde o céu ao chão, se estendendo pelo ar salpicado pelos pequenos flocos, apenas entrecortados pelas cores pastéis de ferro, madeira e tijolo das estruturas. Era difícil só estar neste lugar, mesmo coberta por camadas de suplementos térmicos. Como imaginar condições de vida sem aquecimento em corpos esquálidos cobertos com finas roupas de algodão?

São dois campos de concentração com histórias distintas: Auschwitz I e Birkenau (ou Auschwitz II - Birkenau). Auschwitz foi o primeiro a ser construído e funcionou como uma espécie de projeto piloto de Birkenau, no qual as práticas exercidas em Auschwitz foram elevadas à grande escala. No primeiro, toda a estrutura de prédios está conservada em perfeito estado e abriga o museu, com amostras fixas e temporárias, enquanto no segundo há apenas ruínas e uma única loja de livros e folhetos, com banheiros e aquecimento.

Auschwitz foi criado em 1940 para abrigar o excedente de prisioneiros políticos poloneses, porém com o passar do tempo passou a abrigar pessoas de toda a Europa, sobretudo judeus, mas também testemunhos de Jeová, negros, homossexuais, prostitutas, ladrões e ciganos. A construção iniciou com 20 pavilhões no térreo, mas em 1942 somava 28 prédios de 2 andares que abrigavam entre 13 e 16 mil prisioneiros. Em 1941 iniciou-se a construção de Birkenau, que chegou a abrigar 100 mil pessoas simultaneamente e ao final da guerra contabilizava 60 mil sobreviventes. Estimativas apontam que ali morreram 1,3 milhões de pessoas executadas ou simplesmente negligenciadas por fome, frio e doenças (os números são imprecisos pois boa parte da documentação foi destruída pelos nazistas antes de sua fuga).

Auschwitz I tinha uma única câmera de gás e um crematório para 2 corpos por vez, além de uma sala de julgamento, uma parede de fuzilamento, um espaço para forca de até 8 pessoas, e prisões com cubículos de detenção simples, e celas destinadas à tortura por escassez de espaço (onde deveriam ser colocadas 4 pessoas em um espaço inferior a um metro quadrado por alguns dias), e ainda outras celas destinadas à morte lenta, por fome, falta de oxigênio ou luz. A presença de certa diversidade nesses métodos, principalmente a sala de julgamento - que denota uma preocupação com alguma ordem social e institucional - aponta o fato de que ainda não havia uma banalização da pura execução desenfreada pela asfixia por gás, que se seguiu.

Já Birkenau possuía dois complexos de execução (um foi completamente destruído por explosão durante a evacuação do exército alemão), cada um com duas amplas câmaras de gás acopladas a um crematório, ligadas por um sistema de carris que levava os corpos para os 5 fornos (em cada complexo), que funcionavam em regime integral de 24 horas, com capacidade para cremar 350 corpos por dia: uma verdadeira indústria de execução.

Ao chegarem ao campo, os prisioneiros eram destituídos de seus objetos pessoais, 
despidos e tinham os cabelos raspados. Eram então encaminhados à câmera de gás (principalmente em Birkenau) ou recebiam roupas padrão, em tecido listrado branco e azul (que rapidamente se transformava em tons de cinza), e eram encaminhados para os alojamentos. Os objetos de valor eram confiscados pelos alemães (como joias, dinheiro e obras de arte), enquanto os de pouco valor (como roupas, acessórios e sapatos) eram guardados para serem distribuídos aos soldados. Estes últimos, separados por categoria e classificados, acumulavamse de tal maneira, a despeito da necessidade de distribuição, que formavam verdadeiras montanhas, depois utilizadas para compor um museu.

As exposições apontam a imensidão da tragédia, com são as salas cobertas por objetos até o teto. Ao percorrer os prédios, a sensação é realmente impactante. As salas são enormes, separadas do público por um vidro, como uma vitrine, montadas de maneira a despertar a sensação de uma montanha que sobe as paredes em direção ao teto. A primeira sala é coberta por óculos; aquilo que se parece à distância com um monte de arame embaralhado vai sendo percebido aos poucos, com a aproximação, com milhares de óculos retorcidos e amontoados. A sala seguinte é ocupada por uma vitrine com uma verdadeira montanha de objetos de barba (pinceis, potes e navalhas), que se segue à outra, composta por sapatos, outra por bonecas e brinquedos, outra por próteses de pernas e braços (os prisioneiros com deficiência eram imediatamente exterminados, por não possuírem condições de trabalho), outra por malas, e assim sucessivamente.

Há, também, um pavilhão inteiro composto por paredes cobertas por retratos $3 \times 4 \mathrm{em}$ branco e preto. No início do campo, quando ele ainda não possuía as dimensões de massificação pelo qual ficou conhecido, os prisioneiros eram fotografados para registro. São essas fotos que compõem essa exposição. No dia em que fomos, em uma delas havia uma pequena flor artificial colorida, que quebrava a monotonia dos rostos tristes e esquálidos, deixando no ar a ideia de que algum parente a havia colocado lá.

Figura 2 - Fotos do interior de um dos 24 blocos de Auschwitz I - Exposição Permanente

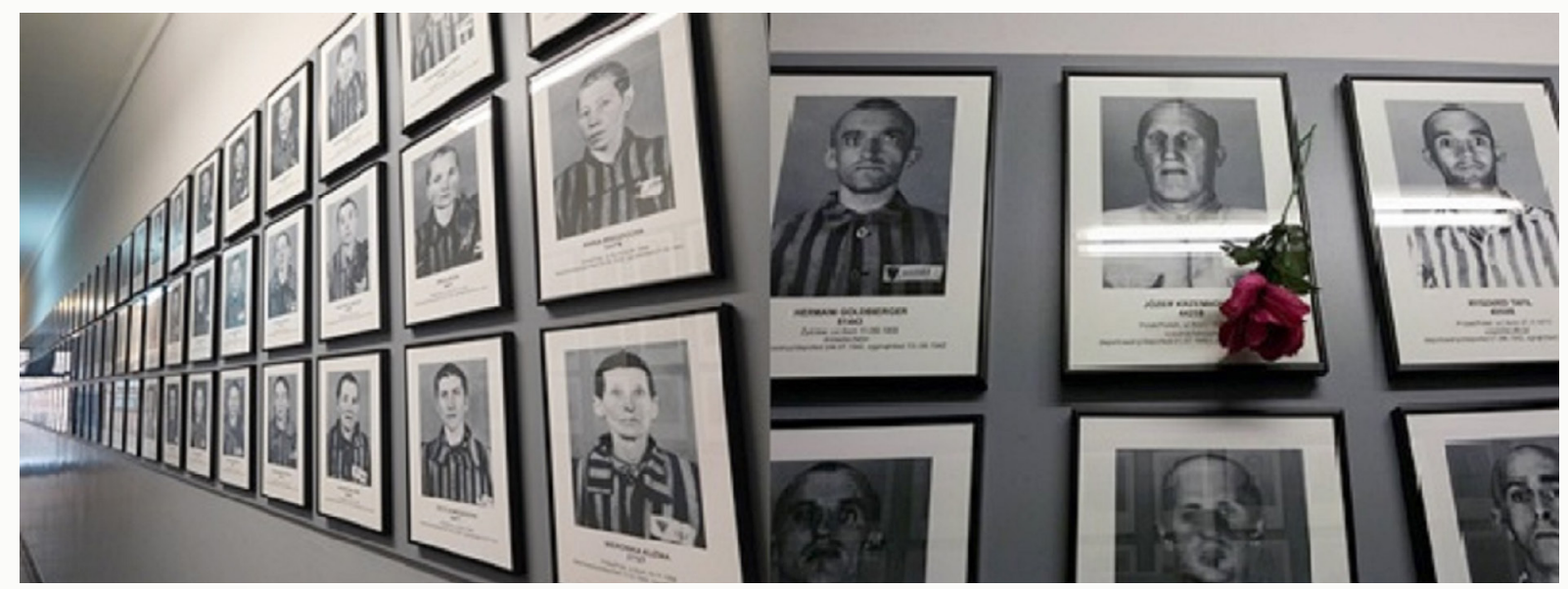

Fonte: Fotografia da autora (18/01/2016)

A mais impressionante, sem dúvida, é a sala de cabelos. Pelo vidro enxerga-se uma 
massa disforme de fibras de cor cinza amarronzada, que não denota em nada seu conteúdo, mais parecendo uma cena de filme de terror, onde uma energia sombria se eleva do inferno sobre a terra. Mas o que se compreende depois é mais aterrorizante: é uma montanha de quase duas toneladas de cabelo humano. Os cabelos dos prisioneiros eram cortados no caminho para a câmera de gás ou logo que as prisioneiras chegavam ao campo, com a justificativa de higienização. Por suas características térmicas, ele era utilizado como matéria prima para a fabricação de tecidos de montaria. Assim, as mulheres eram destituídas daquilo mais próprio que possuíam, parte de seus corpos, em favor dos cavalos, deixando claro que suas vidas tinham menor valor que a dos animais. Está exposto também um pedaço de tecido feito com cabelo humano, assim como um tear e a maquinaria necessária para esta confecção.

Há também uma ampla exposição de fotos e projeção de cenas de prisioneiros captadas pelo exército aliado por ocasião da libertação, em que aparecem corpos esquálidos, que beiram cadáveres, e outra de obras de arte realizadas por sobreviventes que retratam o cotidiano do campo.

Também merece destaque o pavilhão dedicado aos experimentos comandados pelo Dr. Mengele, um dos oficiais mais temidos de todo o campo. Em sua pesquisa sobre genética com crianças gêmeas, brinquedos, tortura e teses científicas se confundem, no que foi uma das situações mais macabras engendradas nessa guerra. Aqui, uma única referência ao Brasil, país em que ele morreu anonimamente por afogamento em 1979 e teve os restos mortais reconhecidos em 1985.

Pegamos um ônibus para atravessar os três quilômetros que separam Auschwitz de Birkenau. A primeira visão do campo é impressionante. Apesar de serem ruínas, temos a dimensão do tamanho da política de massa que era exercida. Tudo é gigante. Pavilhões se estendem ao horizonte, às vezes somente alicerces e chaminés de tijolos restam da antiga estrutura de madeira, formam desenhos no solo coberto de neve ocupando quase toda extensão que os olhos alcançam. Dentro dos poucos prédios conservados, temos noção do amontoamento em que viviam as pessoas, em beliches de três andares, de 1,5 x 1,5 metros que abrigavam cinco pessoas em cada nicho, sobre o chão de barro socado, com um único ponto de aquecimento por pavilhão. De novo, podemos comparar com o cuidado com prisioneiros e com os animais, observando que os estábulos eram amplos e continham uma linha central de aquecimento que irradiava calor a todo o ambiente. A linha férrea corta a neve, construída para levar os prisioneiros em toneladas, dá o tom ao mesmo tempo de matadouro e de ficção, pois lembra diversas imagens de filmes. A sensação é de apequenamento, tudo é imenso. 
Figura 3 - Linha de trem que leva até a câmera de gás em Auschwitz II - Birkenau

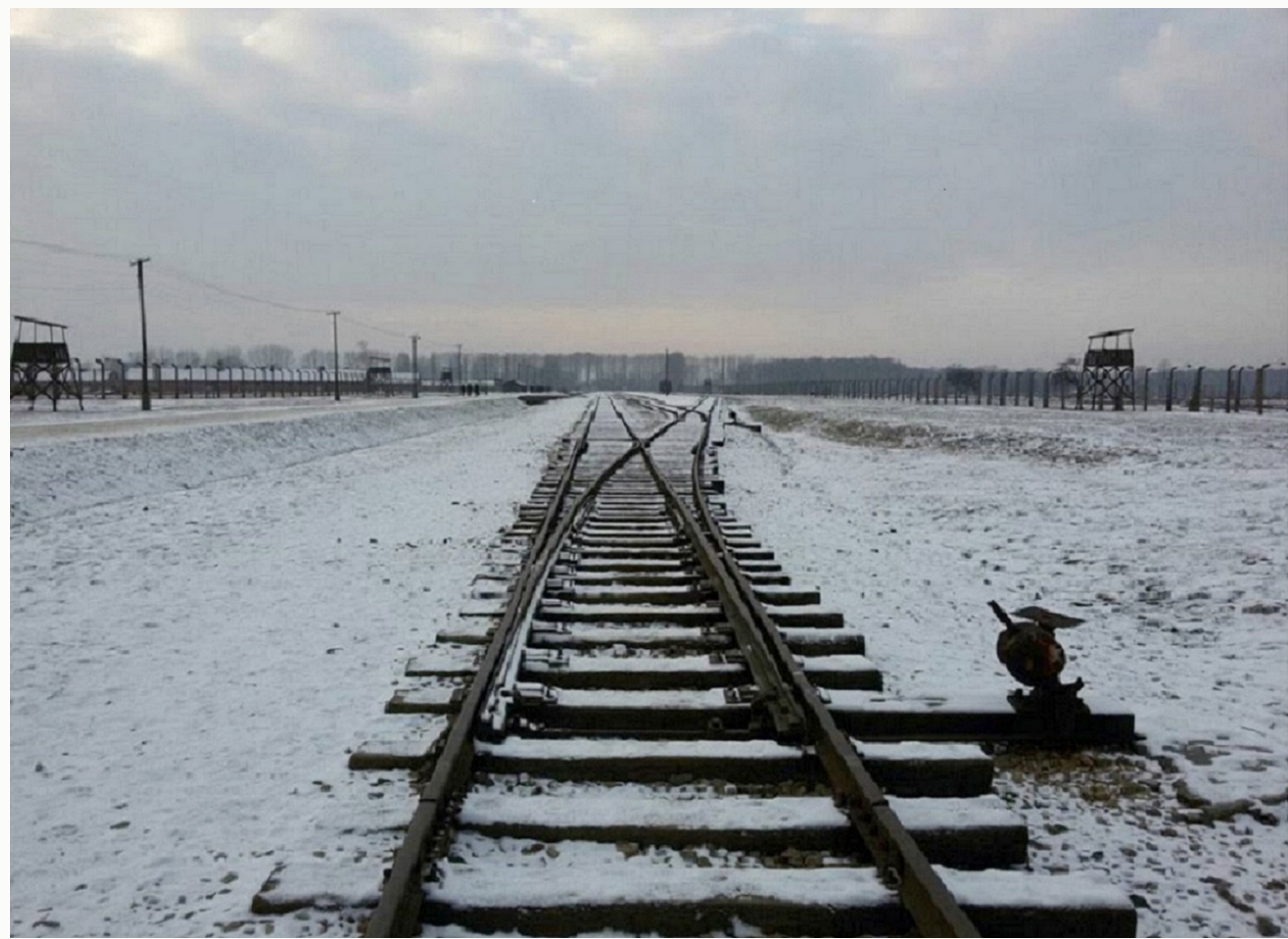

Fonte: Fotografia da autora (18/01/2016)

Uma pergunta parece óbvia: como era possível aos poucos guardas controlar essa multidão? As estratégias utilizadas pela Gestapo aliavam força bruta à manipulação de afetos, incidindo tanto sobre a subjetividade quanto sobre a concretude do espaço. Em primeiro lugar, separavam as famílias: mulheres em uma área, crianças em outra e homens em uma terceira. Era mais difícil articular uma fuga que envolvesse todo o grupo, pois era inimaginável, naquele cenário de total desagregação deixar seus familiares para trás. Essa estratégia gerava um segundo efeito: a necessidade cotidiana de ver a família protagonizava uma ordem de prioridade, deixando a fuga e a revolta para segundo plano.

Em segundo lugar, os nazistas conseguiram manter segredo sobre as câmeras de gás. Segundo os guias do local, como o campo de concentração era imenso e todo compartimentado em áreas isoladas, apenas poucos prisioneiros tinham a ideia do todo. Falavase constantemente em transferências de lugares, mas o que os moradores viam ao longe eram trens fechados partindo e chegando. A maioria das execuções acontecia logo na chegada, pois havia uma plataforma que desembarcava direto na câmara de gás. Os prisioneiros que habitavam o campo não chegavam a ter conhecimento da existência dos recém-chegados, quanto mais de suas mortes.

A terceira estratégia era a mais cruel. Consistia na dissipação de boatos, pelos próprios nazistas, de que a guerra estava acabando. Assim, os prisioneiros pensavam que era melhor suportar só mais um pouco, pois o fim do sofrimento se aproximava. As dificuldades de comunicação entre os prisioneiros tornavam possível a repetição dessa estratégia indefinidas vezes. Esta dificuldade era alimentada por dois principais fatores, a compartimentação do 
campo e a alta rotatividade dos prisioneiros, uma vez que a sobrevida de um trabalhador útil era em média em torno de três meses. São raros os relatos de prisioneiros que, como alguns dos trabalhadores da lista de Schindler, atravessaram os cinco anos de existência do campo. Esse jogo de semeadura de esperança foi, sem dúvida, um dos mais potentes instrumentos de controle.

Não sei se existem na história da humanidade momentos correlatos a esse, certamente que sim, dado que o passado e o presente são assolados por guerras com as mais diferentes justificativas. Vivemos hoje no Brasil uma política de extermínio da população jovem negra, é sabido. O massacre do Carandiru, em 1992, foi semelhante, de certa forma, às execuções de Auschwitz. Mas ainda assim é diferente. O fato de tornar-se política formal de Estado é mais aterrorizante. Mais ainda, se entendermos que exterminou cerca de $25 \%$ da parcela da população somente do país em que se estabeleceu.

\section{Palavras Finais}

O sociólogo camaronês Achille Mbembe desenvolve o conceito de necropolítica para designar um tipo de poder que dita quem deve viver e quem deve morrer. Ele afirma, em aliança com Hanna Arendt, que não há paralelos no mundo para o horror vivido nos campos de concentração. Ele afirma que, talvez por tal razão, o conceito de estado de exceção é frequentemente discutido em relação com o nazismo, e os campos de concentração têm servido como metáfora central para "a violência soberana e destrutiva e como último sinal do poder absoluto do negativo" (Mbembe, 2018, p. 07). É exatamente essa sensação que se tem ao visitar o local de excepcionalidade e, ao mesmo tempo, familiaridade escandalosa que revela a tirania da violência cotidiana que buscamos ignorar. Tudo é muito chocante, disposto ao olhar de tal modo que o visitante vislumbre essa ordem de grandeza e não se esqueça da amplitude do que aconteceu. Contemplar Auschwitz é abrir uma brecha no tempo e habitar o coração do desprezo do homem pelo humano.

Para Rolnik, a pesquisa consiste em voltar o olhar para as estratégias das formações do desejo no campo social. Segundo a autora, para os geógrafos, "a cartografia - diferentemente do mapa, representação de um todo estático - é um desenho que acompanha e se faz ao mesmo tempo que os movimentos de transformação da paisagem" (Rolnik, 1989, p. 15), o que implica necessariamente em afirmar que teoria e prática se constroem mutuamente. Conhecer e fazer se tornam inseparáveis, impedindo qualquer pretensão à neutralidade ou à suposição de um sujeito e de um objeto prévios à relação que os vincula. A intervenção é realizada por um mergulho na experiência que agencia sujeito e objeto, teoria e prática, num mesmo plano de produção ou de coemergência, o plano da experiência. A cartografia como método de pesquisa é o traçado desse plano, acompanhando os efeitos do próprio percurso investigativo sobre o objeto, sobre o pesquisador e sobre a produção de conhecimento (Passos e Barros, 2009).

Cartografia foi o método proposto por Gilles Deleuze e Felix Guattari. Disseminado 
no Brasil inicialmente por Suely Rolnik para o estudo da dimensão processual dos processos de produção da subjetividade. O método cartográfico não equivale a um conjunto de regras a serem aplicadas; consiste em uma construção que requer a habitação do território a ser pesquisado e a implicação do pesquisador no trabalho de campo (Passos e Barros, 2009). As paisagens psicossociais também são cartografáveis, mas nesse caso a cartografia "acompanha e se faz ao mesmo tempo que o desmanchamento de certos mundos - sua perda de sentido - e a formação de outros: mundos que se criam para expressar afetos contemporâneos, em relação aos quais os universos vigentes tornaram-se obsoletos" (Rolnik, 1989, p. 15).

O cartógrafo habita um tipo de sensibilidade que permite dar corpo aos afetos que pedem passagem, mergulhando nas intensidades de seu contato com as experiências do mundo. Para tanto, precisa construir uma abertura especial no seu corpo, que Rolnik intitulou de corpo vibrátil, para "vibrar todas as frequências possíveis e ficar inventando posições a partir das quais essas vibrações encontrem sons, canais de passagem, carona para a existencialização. Ele aceita a vida e se entrega. De corpo e língua" (Rolnik, 1989, p. 16).

O corpo passa a ser então um instrumento de pesquisa, na medida em que seu percurso e sensibilidade registram e dão forma de conhecimento aos afetos que o atravessam. Sobre este aspecto,

Conhecer é, portanto, fazer, criar uma realidade de si e do mundo, o que tem consequências políticas. Quando já não nos contentamos com a mera representação do objeto, quando apostamos que todo conhecimento é uma transformação da realidade, o processo de pesquisar ganha uma complexidade que nos obriga a forçar os limites de nossos procedimentos metodológicos. O método assim, reverte seu sentido, dando primado ao caminho que vai sendo traçado sem determinações ou prescrições de antemão dadas. Restam sempre pistas metodológicas e a direção ético-política que avalia os efeitos da experiência (do conhecer, do pesquisar, do clinicar, etc.) para daí extrair os desvios necessários ao processo de criação (Passos e Barros, 2009, p. 30).

O registro de meu percurso por Paris e Auchwitz, em dias de terror e locais de barbárie, é a tessitura de uma sensibilidade que me permitiu retornar ao Brasil e lançar um olhar sobre experiências de morte, violência, estética e felicidade que balizaram a escrita e lançaram questões desconcertantes pertinentes ao contexto do Rio de Janeiro, mas também de tantos cantos do Brasil e do mundo, pois a humanidade continua elegendo grupos para ocupar o lugar de inimigos e thes infligir sua exterminação, construindo assim o que chamei de maquinarias de produção de morte.

Os motivos que levam à operacionalização do ódio, embora pareçam verdadeiros aos olhos de quem vive aquele momento, sempre são contrariados pela história. Nada, absolutamente nada justifica matar outro ser humano. Contudo, Auschwitz parece ser uma lição que a humanidade ainda não aprendeu. 


\section{Referências Bibliográficas}

ELIAS, Norbert. A solidão dos moribundos. Rio de Janeiro: Zahar, 2001. 107p.

FOUCAULT, Michel. Vigiar e punir: história da violência nas prisões. 14. ed. Petrópolis: Vozes, 1996. 296p.

Em defesa da sociedade. São Paulo: Martins Fontes, 2000. 396p.

MBEMBE, Achille. Necropolítica. São Paulo: n-1 edições, 2018. 80p.

PASSOS, Eduardo e BARROS, Regina. A cartografia como método de pesquisa e intervenção. In: PASSOS, Eduardo; KASTRUP, Virgínia e ESCÓSSIA, Liliana da. (Orgs.) Pistas para o método cartográfico. Porto Alegre: Sulina, p. 17-31, 2009.

ROLNIK, Suely. Cartografia sentimental: transformações contemporâneas do desejo. São Paulo: Estação Liberdade, 1989. 248p.

Recebido em: 30 de dezembro de 2017

Aprovado em: 21 de maio de 2018 